\title{
Peningkatan Kompetensi Dan Kinerja Tenaga Pendidik Paud Melalui Komunikasi Efektif
}

\author{
${ }^{1}$ Renni Kusnaeni, Sri Ratna Chodijah ${ }^{3}$, Heni Fitriani-Mimin Hamidah ${ }^{3}$ \\ ${ }^{1,2,3}$ Dinas Pendidikan Kota Bandung. Jl. Jenderal A. Yani No.239 \\ Email : sriratnach@gmail.com
}

\begin{abstract}
Abstrak
Penelitian tentang "Peningkatan Kompetensi dan Kinerja Tenaga Pendidik PAUD melalui Komunikasi Efektif di Kota Bandung dilatarbelakangi oleh kenyataan menjamurnya lembaga PAUD yang didirikan oleh masyarakat dalam upaya menyukseskan program pemerintah yang disebut PAUDISASI. Oleh karena itu penelitian ini disusun untuk mengetahui gambaran tentang peningkatan kompetensi dan kinerja pendidik melalui komunikasi efektif di lembaga PAUD meliputi perencanaan, pelaksanaan, evaluasi serta faktor pendukung dan penghambatnya. Adapun metode yang digunakan adalah analisis deskriptif kualitatif. Hasil observasi, wawancara dan studi dokumentasi terhadap program pengembangan kompetensi dan kinerja tenaga pendidik di PAUD Al-Jannah dan Psy Center Kota Bandung menunjukkan: 1) Perencanaan program disusun dengan baik; 2) Pelaksanaan program dilakukan oleh semua stakeholder disertai sosialisasi, pengarahan, pencatatan dan pengawasan dari kepala lembaga; 3) Evaluasi program dilakukan oleh yayasan, kepala lembaga secara komunikatif 4) Faktor pendukung berupa tersedianya sarana berbasis IT serta buku-buku panduan kurikulum, adanya alokasi anggaran (walau relatif terbatas), serta mayoritas guru berkualifikasi pendidikan S1. Adapun faktor penghambatnya adalah masih adanya guru yang belum memahami pentingnya pengembangan kompetensi dan kinerja, serta belum terbiasanya guru menghadapi rambu-rambu regulasi yang dilakukan.
\end{abstract}

Kata kunci: kompetensi, kinerja, tenaga pendidik PAUD, komunikasi efektif

\section{Abstract}

The research on "Improving Competency and Performance of PAUD Educators through Effective Communication in Bandung is motivated by the reality of the proliferation of PAUD institutions established by the community in an effort to succeed a government program called PAUDISASI. Therefore this research is structured to find a picture of increasing the competence and performance of educators through effective communication in PAUD institutions including planning, implementation, evaluation and supporting and inhibiting factors. The method used is descriptive qualitative analysis. The results of observations, interviews and documentation studies on the competency development program and the performance of educators in Al-Jannah PAUD and the Bandung City Psy Center show: 1) Program planning is well structured; 2) Program implementation is carried out by all stakeholders accompanied by socialization, direction, recording and supervision from the head of the institution; 3) Program evaluation is carried out by the foundation, the head of the institution communicatively 4) Supporting factors such as the availability of IT-based facilities and curriculum guide books, the existence of budget allocations (although relatively limited), and the majority of teachers qualified with S1 education. The inhibiting factor is that there are still teachers who do not understand the importance of $d$

Keywords: competence, performance, PAUD educators, effective communication 


\section{A. PENDAHULUAN}

Guru adalah pendidik profesional yang mempunyai peran strategis dalam upaya meningkatkan mutu pendidikan. Sebagai seorang pendidik guru wajib memiliki kualifikasi akademik, kompetensi, sertifikat pendidik, sehat jasmani dan rohani, serta memiliki kemampuan untuk mewujudkan tujuan pendidikan nasional dan dituntut untuk memiliki kemampuan dasar yang diperlukan sebagai pendidik pembimbing dan pengajar (Ali Maksum, 2011: 136) mengungkapkan bahwa Guru merupakan faktor yang sangat krusial dalam pendidikan. Hasil kerja Task Force UNESCO terkait upaya meningkatkan kualitas pendidikan di seluruh dunia sampai pada kata akhir, bahwa apapun usaha yang kita lakukan untuk meningkatkan kualitas pendidikan, kualitas guru tetap menjadi faktor kunci,

"...although many variables contribute to effective education, examples being adequate buildings and classrooms, and teaching and learning materials, the most crucial factor is the quality of the interaction that occurs between the teacher and those who are being taught. "(UNESCO, 1996)

Lahirnya Undang-Undang Nomor 14 tentang Guru dan Dosen Tahun 2005 telah menunjukkan secara terarah tentang peran dan kedudukan guru yang strategis dalam mewujudkan amanah pembangunan nasional di bidang pendidikan berupa upaya mencerdaskan kehidupan bangsa dan meningkatkan kualitas manusia Indonesia yang beriman, bertakwa dan berakhlak mulia serta menguasai ilmu pengetahuan, teknologi dan seni dalam menuju masyarakat yang maju, adil, makmur dan beradab berdasarkan Pancasila dan Undang-Undang Dasar 1945. Pada Pasal 39 Ayat (2) Undang-Undang Nomor 20 tentang Sistem Pendidikan Nasional disebutkan bahwa pendidik merupakan tenaga profesional. Kedudukan guru sebagai tenaga profesional mempunyai visi terwujudnya penyelenggaraan pembelajaran sesuai dengan prinsipprinsip profesionalitas untuk memenuhi hak yang sama bagi setiap warga negara dalam memperoleh pendidikan yang bermutu.

Mencermati hasil studi yang dilakukan oleh Saud (2011) pada tahun 2009 tentang lima indikator guru yang bermutu yaitu: pertama memiliki kemampuan profesional (professional capacity), sebagaimana terukur dari ijazah, jenjang pendidikan, jabatan dan golongan, serta pelatihan. Kedua melakukan upaya profesional (professional efforts), sebagaimana terukur dari kegiatan mengajar, pengabdian dan penelitian. Ketiga, waktu yang dicurahkan untuk kegiatan profesional (teacher's time), sebagaimana terukur dari masa jabatan 
pengalaman mengajar serta lainnya.

Keempat, kesesuaian antara keahlian dan pekerjaannya (link and match), sebagaimana terukur dari mata pelajaran yang diampu, apakah telah sesuai dengan spesialisasinya atau tidak, serta kelima, tingkat kesejahteraan (prosperiousity) sebagaimana terukur dari upah, honor atau penghasilan rutinnya.

Kenyataan di lapangan menunjukkan banyak pendidik belum memiliki kelima indikator guru bermutu tersebut, sebagai contoh; untuk indikator yang pertama, masih banyak pendidik yang tidak memiliki kemampuan profesional sesuai pendidikan yang ditempuh serta ijazah kelulusan yang dimilikinya, dibuktikan dengan kekeliruan-kekeliruan dalam praktik mengajar di dalam kelas yang tidak sesuai dengan pengetahuan yang didapat, termasuk banyak guru yang menduduki jabatan kepala sekolah yang tidak berfungsi sebagaimana mestinya sehingga berdampak terhadap kompetensi guru yang ada di wilayah binaannya dan berdampak pula terhadap mutu hasil belajar. Indikator kedua masih banyak guru senang berada di zona aman sebagai pengajar, tidak menyukai inovasi, tantangan, senang dengan rutinitas yang monoton, tidak dinamis, cukup puas dengan apa yang didapatnya saat ini, tidak ingin melakukan upaya profesional melalui pengembangan kompetensi atas prakarsa mandiri sehingga banyak pendidik yang melaksanakan tugasnya dengan berbekal ilmu yang sudah ketinggalan jaman

(Arifin D dan Pipin, 2011). Indikator ketiga masih banyak pendidik yang mempunyai pengalaman mengajar yang sudah sangat lama tetapi tidak pernah menunjukkan kecintaannya terhadap pekerjaan sebagai pendidik, tetapi mengubah dirinya menjadi hanya pengajar atau pentransfer ilmu saja yang tugasnya menggugurkan kewajiban demi mengejar jam mengajar dan tidak senang berlama-lama membimbing siswanya untuk membentuk kepribadian siswa dengan penuh tanggungjawab kecuali bila ada tujuan tertentu misalnya mengejar tunjangan profesi, insentif, dan hal-hal yang sifatnya hak bukan kewajiban. Indikator keempat adalah ketidaksesuaian antara latar belakang pendidikan dengan tugas yang diampunya sehingga banyak guru yang tidak menguasai materi yang diajarkan kepada siswanya dan sering terjadi pemahaman dadakan yang mengakibatkan proses pembelajaran menjadi tidak menarik. Indikator ke lima banyak pendidik yang mendapatkan honorarium dibawah standar upah minimum regional sehingga berdampak buruk terhadap tingkat kesejahteraan dan kinerjanya. Dalam tataran pendidik PAUD hal tersebut di atas memunculkan keprihatinan yang lebih dibandingkan dengan keprihatinan terhadap yang terjadi pada pendidik di jenjang lain mengingat posisi PAUD berada pada posisi yang bersifat fundamental. 
Munculnya program PAUDISASI tahun 2013, disusul dengan program satu desa satu PAUD tahun 2014 dari direktorat formal (KB, TPA, dan SPS ) bagai jamur di musim hujan karena program ini langsung menukik pada kinerja para pemimpin di pemerintahan daerah dan secara langsung terukur melalui pencapaian angka partisipasi kasar (APK) anak usia dini di daerah binaannya. Hal ini berdampak signifikan terhadap bertambahnya jumlah pendidik anak usia dini dengan latar belakang pendidikan yang beragam dan tidak memenuhi persyaratan seorang pendidik PAUD. Di satu sisi menambah semarak dunia PAUD di sisi lain menimbulkan kekhawatiran akan dibawa kemana arah tujuan pendidikan bagi calon-calon penerus bangsa ini sebab secara realita pertumbuhan lembaga PAUD yang marak ini tidak disertai dengan seleksi yang ketat bagi calon pendidiknya dan kurangnya pembekalan, pembinaan dan pelatihan yang merata karena keterbatasan kemampuan pemerintah dalam hal pembiayaan, kontrol dari yang berwenang serta pengetahuan para penilik dan pengawas di bidang pendidikan anak usia dini yang terbatas sehingga kompetensi pendidik di lembaga PAUD yang bermunculan ini betul-betul harus mendapatkan perhatian yang serius dan kerjasama yang baik dari berbagai pihak terutama dari pengelola Lembaga PAUD itu sendiri dalam melakukan pembinaan dan peningkatan kompetensi guru/pendidik di
PAUD di Kemendikbud memicu tumbuhnya lembaga-lembaga PAUD terutama lembaga-lembaga PAUD non lembaganya masing-masing serta kemauan yang tinggi untuk menambah ilmu pengetahuan dan keterampilan dalam mendidik anak usia dini. Sebagai kajian manajemen yang mendukung strategi komunikasi yang dibutuhkan pendidikan maka menurut George R.Terry. (2015), dapat diarahkan kepada pengolahan pesan yang diberdayakan saat mengelola SDM guru.

Peran Kepala Sekolah sebagai sumber informasi di lembaga PAUD sangat dibutuhkan oleh guru-guru, terkadang tidak berjalan optimal, Komunikasi efektif antara guru dan kepala sekolah diperlukan, agar Kepala Sekolah dapat penyampaian informasi (pesan) kepada guru, dan guru dapat meningkatkan kinerja dan dapat melaksanakan informasi tersebut kepada anak didik. Komunikasi Kepala Sekolah yang diperlukan dalam meningkatkan kompetensi dan kinerja diantaranya adalah disiplin guru, yaitu memberikan contoh teladan dengan hadir ke sekolah tepat waktu dan pulang paling akhir; dan komunikasi kepala sekolah dalam meningkatkan tanggung jawab guru yaitu komunikasi antar pribadi dan komunikasi dalam memecahkan masalah di dalam pembelajaran dengan cara berkoordinasi dan mencari solusi bersama-sama dengan komite dan pengawas sekolah, serta Dinas Pendidikan terkait. Selain itu, kepala 
sekolah juga harus mampu memberikan dorongan dan pembinaan dalam rangka peningkatan profesionalisme guru, kedisiplinan dan tanggungjawab guru secara efektif dan efesien.

tenaga pendidik PAUD mutlak perlu diperbaiki, dijaga, dan ditingkatkan melalui komunikasi efektif yang dibangun oleh seluruh stakeholder di Lembaga PAUD tersebut. Pengembangan dimaksudkan untuk merangsang, memelihara dan meningkatkan kualitas pendidik berdasar pada kebutuhan individu untuk menjalani proses profesionalisasi .

\section{B. KAJIAN LITERATUR}

\section{Komunikasi Efektif}

Menurut Jalaluddin Rahmat dalam bukunya Psikologi Komunikasi menyebutkan, komunikasi yang efektif ditandai dengan adanya pengertian, dapat menimbulkan kesenangan, mempengaruhi sikap, meningkatkan hubungan sosial yang baik, dan pada akhirnya menimbulkan suatu tindakan.

Menurut Mc. Crosky Larson dan Knapp, komunikasi yang efektif dapat dicapai dengan mengusahakan ketepatan (accuracy) yang paling tinggi derajatnya antara komunikator dan komunikan dalam proses komunikasi. Komunikasi yang efektif hanya dapat terjadi jika komunikator dan komunikan memiliki persamaan dalam pengertian, sikap dan bahasa. Sebuah komunikasi dikatakan efektif apabila:
Berangkat dari asumsi di atas, penulis memandang bahwa pengembangan kompetensi dan kinerja

a) Pesan dapat diterima dan dimengerti serta dipahami sebagaimana yang dimaksud oleh pengirimnya.

b) Pesan yang disampaikan oleh pengirim dapat disetujui oleh penerima dan ditindaklanjuti dengan perbuatan yang diminati oleh pengirim.

c) Tidak ada hambatan yang berarti untuk melakukan apa yang seharusnya dilakukan untuk menindaklanjuti pesan yang dikirim.

\section{Kompetensi Tenaga Pendidik PAUD}

Kajian mengenai kompetensi guru PAUD, pada dasanya bersumber dari peraturan pemerintah yang sama dengan jenjang pendidikan di atas. Sebagaimana dijelaskan dalam Peraturan Pemerintah No. 19 tahun 2005 pasal 28, ayat 3 disebutkan bahwa kompetensi guru sebagai agen pembelajaran pada jenjang pendidikan dasar dan menengah serta pendidikan anak usia dini meliputi; (1) kompetensi pedagogik, (2) kompetensi kepribadian, (3) kompetensi profesional, dan (4) kompetensi sosial. Standar kompetensi guru dikembangkan secara utuh dari empat kompetensi utama tersebut. Keempat kompetensi tersebut 
terintegrasi dalam kinerja guru. Dari keempat kompetensi tersebut maka untuk guru jenjang PAUD sebenarnya lebih difokuskan salah satunya kepada upaya membangun komunikasi yang efektif dengan anak. Hal ini sangat penting mengingat kebanyakan dalam personal yang kuat yang harus dilakukan pendidikan. Ketika itu semua terpenuhi maka kinerja pendidik PAUD dapat dibantu untuk lebih melesat tinggi.

\section{METODE PENELITIAN}

Mencermati permasalahan dan tujuan penelitian, maka metode yang dipandang relevan adalah metode analisis deskriptif kualitatif. Alasan dari penggunaan pendekatan deskriptif kualitatif adalah karena permasalahan dalam penelitian ini belum jelas, holistik, kompleks, dinamis dan penuh makna. Selain itu peneliti juga bermaksud mendeskripsikan atau menggambarkan kondisi penelitian apa adanya dari peningkatan kompetensi dan kinerja tenaga pendidik PAUD melalui komunikasi efektif di Kota Bandung. Hal ini sesuai dengan pendapat Sukmadinata (2007: 73) yang menyatakan bahwa penelitian deskriptif tidak memberikan perlakuan, manipulasi atau pengubahan pada variabel-variabel bebas, tetapi menggambarkan suatu kondisi apa adanya.

Selain itu, penelitian ini juga ditujukan untuk memahami fenomenafenomena sosial dari sudut atau perspektif partisipan mengenai praktek komunikasi antara pendidik PAUD dengan anak usia dini dituntut lebih interaktif. Jika guru memiliki daya Tarik personal maka untuk menciptakan suasana belajar bagi anak PAUD membutuhkan metode Public Relations

peningkatan kompetensi dan kinerja tenaga pendidik yang dilaksanakan di dua Lembaga PAUD yang berbeda. Partisipan adalah orang-orang yang diajak berwawancara, diobservasi, diminta memberikan data, pendapat, pemikiran, dan persepsi (Sukmadinata, 2007: 94). Dengan demikian penelitian kualitatif ini adalah upaya untuk menemukan, menggambarkan, menganalisis, dan menafsirkan data empiris di lapangan dengan interpretasi yang tepat terhadap suatu permasalahan terkait dengan pengembangan kompetensi dan kinerja tenaga pendidik PAUD melalui komunikasi efektif di Kota Bandung.

Penelitian ini tidak bermaksud menguji hipotesis, tetapi mendeskripsikan secara mendalam fenomena tentang peningkatan kompetensi dan kinerja tenaga pendidik PAUD melalui komunikasi efektif di Kota Bandung. Dengan demikian pendekatan yang digunakan dalam penelitian ini adalah untuk mendapatkan data yang mendalam dan mengandung makna. Makna adalah data sebenarnya, data yang pasti yang merupakan suatu nilai di balik data yang tampak. 
Sesuai dengan metode penelitian yang digunakan yaitu metode deskriptif kualitatif, maka data yang dihasilkan pun biasanya berupa data deskriptif, akan diperoleh melalui observasi, wawancara, dan studi dokumentasi. Hal ini sesuai dengan Bogdan dan Taylor (Soegiono, 1998: 3) yang mengemukakan bahwa metodologi kualitatif merupakan masalah yang dikembangkan sesuai dengan tujuan utama penelitian. Oleh sebab itu, penggunaan pendekatan ini berdasarkan tujuan untuk mengkaji, mendeskripsikan perencanaan, pelaksanaan dan evaluasi peningkatan kompetensi dan kinerja tenaga pendidik melalui komunikasi efektif PAUD di Kota Bandung.

Sedangkan alasan peneliti menggunakan pendekatan kualitatif adalah:

a. Penelitian ini dilakukan pada fenomena yang ada dan sedang berlangsung, dan akan mencari gambaran suatu kondisi apa adanya, yaitu tentang peningkatan kompetensi dan kinerja tenaga pendidik PAUD melalui komunikasi efektif di Kota Bandung.

b. Penelitian ini dilakukan untuk mendeskripsikan dan menganalisis fenomena, peristiwa, aktivitas sosial, pemikiran orang secara individual atau kelompok. Dalam hal ini peneliti akan mendeskripsikan dan menganalisis Sedangkan pendekatan sesuai karakteristik, khusus lembaga TK Islam Al Jannah ditambah pendekatan prosedur penelitian yang menghasilkan data deskriptif berupa kata-kata tertulis maupun lisan dari orang-orang dan perilaku yang diamati.

Tujuan dari penggunaan pendekatan kualitatif pada penelitian ini juga ditujukan untuk mengkaji, mendeskripsikan, dan mengevaluasi

peningkatan kompetensi dan kinerja tenaga pendidik PAUD melalui komunikasi efektif di Kota Bandung yang meliputi perencanaan, pelaksanaan, dan evaluasi serta faktor pendukung dan penghambatnya, dalam rangka meningkatkan kompetensi dan kinerja pendidik PAUD.

\section{HASIL DAN PEMBAHASAN}

Perencanaan Peningkatan Kompetensi dan Kinerja Pendidik melalui komunikasi efektif di lembaga PAUD Islam Al Jannah dan Psycentre Bandung dirumuskan dengan menggunakan metode dan pendekatan komunikasi yang sama secara prinsip tetapi berbeda secara karakteristik, Mulyasa E (2012). Di kedua lembaga pendekatan komunikasi yang digunakan adalah pendekatan umum berupa pembinaan dan arahan tentang pentingnya meningkatkan kualitas diri yang berdampak signifikan terhadap jenjang karir pendidik serta berdampak terhadap mutu lulusan lembaga PAUD.

keagamaan (komunikasi religi) berbentuk pengajian rutin mendalami $\mathrm{Al}$ Qur'an yang merupakan upaya kepala 
lembaga dalam menanamkan kewajiban pendidik untuk memahami bahwa yang menjadi rujukan dalam melaksanakan pendidikan di TK Al Jannah adalah ayat-ayat Al-Quran dan hadis Nabi yang senantiasa untuk amal makruf nahi munkar demi tercapainya kepribadian muslim yang sejati yang berimbas pada suasana kerja yang sehat.

Pelaksanaan peningkatan kompetensi dan peningkatan kinerja pendidik melalui komunikasi efektif di kedua lembaga meliputi 1). Peningkatan kompetensi profesional dan pedagogis melalui workshop pembuatan silabus, pelaksanaan dan supervisi terhadap pelaksanaan pembuatan administrasi guru, display kelas, display tema dan pembuatan alat peraga sepanjang satu tahun pelajaran, proses bimbingan guru terhadap anak yang mempunyai hambatan, keterlaksanaan pengembangan diri melalui pelatihan, seminar dan kegiatan di gugus, pembinaan psikologi yang keseluruhannya sangat dibutuhkan sebagai panduan dalam melaksanakan proses pembelajaran serta menjadi motivasi dan bahan refleksi terhadap kinerja pendidik dalam melaksanakan tugasnya melalui reward dan funishment. 2). Peningkatan kompetensi sosial dan kepribadian berupa pembinaan awal dari yayasan dan kepala sekolah (tentang kepegawaian, tata tertib pengembangan kompetensi dan peningkatan kinerja pendidik.

a. Faktor pendukung di Lembaga PAUD TK Aljannah : a). Kepala dan peraturan personel), keterlaksanaan SOP, jadwal kegiatan guru di dalam dan luar pembelajaran, piket harian, serta pelatihan, seminar, diklat, in house training serta kegiatan di organisasi profesi (IGTKI dan PKG) serta peningkatan Kompetensi keagamaan melalui pengajian rutin.

Evaluasi atas keterlaksanaan peningkatan kompetensi dan kinerja pendidik melalui komunikasi efektif di kedua lembaga PAUD ditujukan untuk pengecekan kesesuaian perencanaan dengan pelaksanaan serta implikasinya terhadap peningkatan kompetensi dan kinerja pendidik. Evaluasi dilakukan oleh seluruh stakehoder pendidikan di lembaga PAUD yaitu : a) Yayasan yang berperan mengevaluasi pada ketercapaian program sekolah secara keseluruhan dan kinerja kepala sekolah sesuai dengan delapan standar nasional pendidikan; b) Kepala sekolah yang mengevaluasi ketercapaian peningkatan kompetensi dan kinerja para guru; c) Evaluasi juga dilakukan oleh Guru menyangkut ketercapaian proses dan hasil pembelajaran serta d) Pengawas sekolah yang bertanggung jawab atas keseluruhan program kegiatan kepala sekolah dan guru yang berstandar pada empat kompetensi dasar kepala dan guru.

Faktor pendukung dan penghambat terselenggaranya manajemen

TK sangat memahami tupoksi dan pentingnya komunikasi efektif dalam berinteraksi, b) Tersedia alokasi dana oleh 
yayasan, c) adanya sarana baik sarana berbasis IT maupun buku pedoman kurikulum dan pustaka guru, d) rasio guru sesuai standar proses, e) kompetensi pedagogik guru (8 dari 10 guru bergelar SPd. AUD), f) Peran aktif

c. peningkatan kompetensi menyebabkan pencapaian kinerja guru menjadi tidak maksimal.

d. Faktor pendukung di Lembaga PAUD Kelompok Bermain Psycentre : a) Sikap responsif dan komitmen yayasan terhadap kemajuan lembaga PAUD Psycenter, b) mempunyai biro psikologi yang bersatu dengan manejemen yayasan Psycenter, sehingga memudahkan dalam pengembangan potensi anak secara optimal, c) Hampir seluruh guru sudah mempunyai kualifikasi S1 (80\%), d) Sarana Prasarana cukup lengkap (program RAKS, dokumen kurikulum, buku-buku pendukung yang sesuai, laptop, jaringan internet), e) Tingkat kretivitas warga sekolah dalam mendukung lembaga PAUD baik, f) Kerjasama dengan lembaga lain terjalin harmonis dan saling mendukung.

ditambah dengan peningkatan kompetensi keagamaan bagi pendidik pengawas TK, serta g) adanya kerjasama yang baik dengan instasi pemerintah maupun organisasi profesi.

b. Faktor penghambat : kurangnya konsistensi guru dalam mengikuti setiap program

e. Faktor penghambat : a) guru dan staf belum terbiasa dengan rambu-rambu regulasi yang diberlakukan; b) kemauan dan kemampuan sumber daya manusia (SDM) belum optimal, terutama kemampuan Kepala Sekolah dalam mengkomunikasikan berbagai tugas yang harus dilaksanakan oleh guru; c) guru yang belum sepenuhnya memahami pentingnya program pengembangan kompetensi.

\section{E. SIMPULAN \\ REKOMENDASI}

DAN

\section{Simpulan}

Peningkatan kompetensi dan kinerja pendidik PAUD melalui komunikasi efektif meliputi perencanaan, pelaksanaan serta evaluasi, dilakukan oleh kepala lembaga PAUD Al Jannah dan Psycentre diarahkan pada 4 kompetensi guru yaitu kompetensi profesional dan pedagogik serta kompetensi sosial dan kepribadian TK Al Jannah. Pada pelaksanaannya peningkatan kompetensi dan 
peningkatan kinerja pendidik PAUD pada kedua lembaga bertujuan sama yaitu meningkatkan kompetensi pendidik baik di dalam lingkungan lembaga maupun di luar lembaga melalui memberikan rangsangan, memelihara dan meningkatkan kualitas pendidik berdasar kepada kebutuhan individu untuk menjalani proses profesionalisasi yang pada akhirnya tidak konsisten terhadap jadwal yang telah disepakati.

\section{Rekomendasi}

Sejalan dengan temuan lapangan dan hasil analisis Manajemen pengembangan kompetensi dan kinerja pendidik PAUD di dua lembaga di kota bandung, ada beberapa yang ingin peneliti sampaikan sebagai rekomendasi bagi pihak-pihak terkait. Adapun rekomendasi tersebut adalah sebagai berikut:

\section{a. Pendidik}

Pendidik PAUD disarankan untuk tidak terlena berada di zona aman, Guru Paud harus senantiasa melakukan pengembangan diri melalui berbagai kesempatan untuk meningkatkan kompetensinya , melakukan inovasi dan tanggap terhadap berbagai perubahan, senantiasa konsekwen dan komitmen terhadap profesi. Pendidik PAUD senantiasa bekerjasama dengan rekan kerja dalam mendukung program pengembangan kompetensi dan berkomunikasi dengan seluruh stake holder dalam menjaga kualitas lembaga maupun pendidik berimplikasi terhadap kualitas mutu lulusan atau output lembaga. Selain itu kedua kepala lembaga itu juga mengidentifikasi kendala-kendala yang timbul serta mencari solusi untuk mengatasinya baik dari sisi guru, kepala lembaga maupun warga sekolah lainnya; kendala antara lain berupa biaya, waktu, atau kelalaian misalnya

kinerja yang diprogramkan oleh lembaga maupun yang diselenggarakan di luar lembaga sehingga kemampuan profesional tetap terjaga.

\section{b. Kepala Lembaga PAUD}

Kepala Lembaga PAUD disarankan melakukan kemampuan manajerialnya untuk menjaga lembaganya tetap berkualitas melalui ; a) menyusun perencanaan program pengembangan kompetensi dan kinerja pendidik yang didasarkan pada kebutuhan (need analysis) sehingga rencana program akan efektif. b) Memberi kesempatan seluas-luasnya kepada pendidik untuk meningkatkan kompetensinya baik secara mandiri maupun dibiayai pemerintah c) Melakukan pengawasan terhadap kinerja pendidik baik yang teprogram maupun tidak terprogram melalui supervisi kelas dan Penilaian Kinerja Guru (PKG). d) Menjalin kerjasama yang baik dan

\section{c. Pengambil Kebijakan}

Bagi pengambil kebijakan dalam hal ini Dinas Pendidikan Kota 
Bandung diharapkan agar a) memberikan perhatian yang lebih baik terhadap peningkatan mutu lembaga PAUD di kota Bandung melalui pemberian ijin operasional pendirian lembaga PAUD baru secara ketat dengan memperhatikan persyaratan yang sudah menjadi standar lembaga layak operasional sesuai dengan persyaratan 8 standar Kelompok Bermain, Satuan PAUD Sejenis dan Taman Penitipan Anak, agar pendidik PAUD dapat mengikuti program peningkatan dan pengembangan kompetensi dengan tenang tanpa berpikir biaya, c) Mengangkat dan memberdayakan pengawas TK dan penilik PAUD non formal ( KB, SPS,TPA) untuk melaksanakan tugas sesuai kapasitas keahliannya dalam memberikan pengawasan terhadap pengelolaan lembaga PAUD yang ada di kota Bandung dengan lebih fokus kepada proses pendidikan yang dilakukan oleh para pendidik.

\section{d. Peneliti Selanjutnya}

Bagi peneliti yang ingin melakukan penelitian lanjutan terkait dengan Manajemen Pengembangan kompetensi dan kinerja pendidik paud di lembaga PAUD di kota Bandung diharapkan penelitian ini dapat dijadikan inspirasi untuk mengkaji lebih dalam tentang

Peraturan Pemerintah No. 19 tahun 2005 pasal 28, ayat 3, tentang Kompetensi Guru. terutama pada standar pendidik dan tenaga kependidikan sehingga fenomena pendidik PAUD yang kurang kompeten di bidangnya tidak akan bertambah b) Menambah jumlah dana peningkatan mutu bagi pendidik PAUD berbagai layanan dengan peruntukan yang merata untuk TK yang ada di jalur formal dan untuk manajemen pengembangan kompetensi pendidik PAUD, ditinjau dari berbagai aspek, mengingat masing-masing lembaga PAUD memiliki strategi dan pendekatan tersendiri.

\section{F. REFERENSI}

Arifin D dan Pipin (2011) Keprofesionalan seorang Guru Bandung : Pustaka AlKasyaf

Direktorat Pendidikan Anak Usia Dini (2009). Peraturan Menteri Pendidikan Nasional No 58 Tentang Standar Pendidikan Anak Usia Dini Jakarta:

George R.Terry.(2015).Asas-asas manajemen. Bandung Alumni PT

Maksum

A.(2008).

KompetensiKomunikasiGuru

PAUD. Jurnal Pengembangan

Profesi ,LPMP Jawa Barat.

Mulyasa E (2012). Manajemen PAUD Bandung Remaja Rosdakarya PT Rakhmat, Jalaludin. 2013. Psikologi Komunikasi.Bandung: PT. Remaja Rosda Karya 
Sukmadinata (2007). Metode Penelitian

Pendidikan.Bandung: Alphabeta.

Seogiyono (2007). Metode Penelitian

Pendidikan (Pendekatan

Kuantitatif, Kualitatif, dan $R$ \&

$D)$. Bandung: Alfabeta

UNESCO. (1996).AnnualReportof

EducationalandCommunication

Practices. France: CentralOffice-

Unesco.

Udin S Syaud (2011) Pengembangan

Profesi Guru. Bandung:

Alphabeta. 